\title{
Histopathology in Iraq: Reliable Diagnostics in Spite of Shortages
}

\author{
Irak'ta Histopatoloji: Sıkıntılara Rağmen Güvenilir Tanı
}

\author{
Sergei JARGIN
}

Department of Pathological Anatomy, Peoples' Friendship University of Russia, MOSCOW, RUSSIAN FEDERATION

\begin{abstract}
The purpose of this study is to understand the status of Pathology in Iraq evaluating health problems in the country. Pathologists in Iraq are at the top of the level of scientific knowledge and professional responsibility. Although there are adequate modern equipment, lack of chemicals and experienced technical service inadequacies are evident. Special stains and immunohistochemistry are performed only in some of the private laboratories. Consultation is often carried out within the department, but external consultations are less frequent. In terms of specialized training, highly motivated, knowledgeable rotators and residents are available. Technical personnel, even though not sufficient in number, have got adequate professional training and skills. There are many problems in running quality control programs in the laboratories. As a result, the progress in the health system of Iraq, and therefore the status of pathology discipline, are of great importance for the development of the country. Foreign pathologists as a volunteer or a staff will provide the objective points of identifying the problems and will help to find a solution.
\end{abstract}

Key Words: Iraq, Histopathology, Laboratories
ÖZ

$\mathrm{Bu}$ yazının amac1; Irak'ta Tibbi Patoloji'nin durumuna saptama yaparak, ülkede sağlık alanındaki problemlere yönelik yaşanan algılamayı geliştirmektir. Irak’ta Patoloji Uzmanları'nın bilgi düzeyleri genel olarak üst seviyededir ve profesyonel sorumluluk bilinci gelişmiştir. Yeterli modern cihazlar bulunmasına karşı, kimyasallarda eksiklik ve teknik servis yetersizlikleri yaşanmaktadır. Özel boyalar ve immunohistokimya sadece bazı özel laboratuvarlarda yapılmaktadır. Bölüm içi konsültasyon sıklıkla yapılmakta, ancak dış konsültasyonlar daha enderdir. Uzmanlık eğitimi açısından bakıldığında, oldukça motive, bilgili asistanlar ve rotasyonerler bulunmaktadır. Teknik elemanlar, sayısal açıdan az sayıda olmalarına rağmen, profesyonel anlamda yeterli eğitim almışlardır. Kalite kontrol programlarının yürütülmemesine bağlı sorunlar yaşanmaktadır. Sonuç olarak Irak’ta sağlık sisteminin ve dolayısı ile Tibbi Patoloji’nin, ülkenin gelişmesi açısından önemi büyüktür. Yabancı patologların gönüllü ya da görevli olarak yapacakları ziyaretler, nesnel açıdan sorunların saptanmasına ve çözüm bulunmasına yardımcı olacaktır.

Anahtar Sözcükler: Irak, Histopatoloji, Laboratuvar
Previously, I reported on some aspects of health care in Iraq (1), which were discussed also at the Nursing Conference in Baghdad on 15 July 2003. I was in a clinical attachment at the Department of Pathology, Teaching Laboratories (led by Dr. Jassem T. Al-Khafaji), at the Baghdad Teaching Hospital in the period May-July 2003, working simultaneously parttime at a non-governmental organization (NGO) as a project officer in the field of health care assistance. Late in July 2003, I visited several hospitals in Basra, Mosul, Kirkuk and Erbil. In Basra, I had an opportunity to observe the work of the Department of Pathology of the Teaching Hospital in some detail. Having returned to Russia, I remained in contact with colleagues in Iraq, and met some of them at the 21st European Congress of Pathology held in Istanbul on September 8-13, 2007. The main point that has driven me

Received : 09.08.2010

Accepted : 19.01.2011 to write this and the previous (1) letters was understanding by analogy of some problems of health care in Iraq because of their similarity to those in the former Soviet Union and, probably, in the whole former Eastern Bloc. To name but a few common problems: relatively low social status of nurses and medical technicians resulting in their shortage; limited availability of modern, internationally used professional literature; very limited number of methods available in the everyday practice of pathology even at large university hospitals; shortage of chemicals and modern equipment, irregular technical servicing of the equipment (2). Some social problems and those related to the management of the public health are apparently also of a similar nature. The vacuum remaining after the collapse of the Baath regime was partly filled by criminal structures, who care

Correspondence: Sergei JARGIN

Department of Pathological Anatomy, Peoples' Friendship University of Russia, Clementovski per 6-82, 115184 MOSCOW, RUSSIA

E-mail: sjargin@mail.ru Phone: +7 4959516788 
for disorder, impeding restoration of the economy, which would create working places and distract young people from insurgency. It is known in Iraq that they are fused with the governing spheres of the previous regime. Educational and employment policy of the Baath regime resulted in shortage of properly trained nurses and laboratory technicians (2). Relatively low salaries and prestige resulted in the influx of insufficiently trained persons. One of the impediments to quality care is the fact that female personnel usually don't work at night. Female nurses and doctors are engaged during the daytime, which in Iraq means until around 1 p.m. The rest of the time predominantly male nurses are working. Neglect of prescriptions by the nurses was often reported by doctors. Responsible physicians make their prescriptions, injections and others, themselves, not relying upon the nurses. Management of hospitals tended to belittle these problems. Furthermore, shortage of physicians was discussed at the Nursing Conference. Having resided in the "Doctor's House", I observed in fact overabundance of doctors in the Medical City of Baghdad. Many young physicians came to the hospital irregularly and did not participate on night duties; they prefer to stay in large clinical centers sometimes almost without professional engagement. Shortage of doctors in small towns and rural areas is a consequence.

More details should be added with regard to the area of pathology. First about advantages: English language is used in the medical education and for clinical records in hospitals; rather new literature is used both in histopathology and in clinical departments, although, in general, there is a shortage of modern books. Two editions were mainly used in the Department of Pathology: Ackerman's Surgical Pathology and the Lever's Histopathology of the Skin. Pathologists have high level of knowledge, are responsible and attentive while performing histopathological examinations. Some of them had studied or practiced in Western countries. There is modern equipment in the Department, but a part of it, e.g. a freezing microtome and an automatic tissue processor, were out of use because of insufficient servicing and shortage of chemicals. Only hematoxylin and eosin stain was applied in histopathology in Baghdad Teaching Hospital; but special stains, immunohistochemistry, and other modern methods were performed by some private laboratories, thus being, in principle, available for patients. Intra-departmental consultations were frequent and efficient; in fact, difficult cases were examined by all pathologists of the Department. External consultations with participation of specialists from other institutions were less frequent, but they were performed in case of indications, such as in an osteoblastoma case discussed below. With regard to the continuing medical education, it is difficult to give a comprehensive overview from a position of a volunteer in a Department of Pathology, but there were residents and rotators in the Department, who were highly motivated and demonstrated a good level of professional knowledge. With regard to the residents in clinical departments, as mentioned above, their number was rather high in the Medical City of Baghdad, while not all of them were regularly engaged in professional activity.

Some drawbacks in the practice of pathology should be mentioned, which obviously resulted from shortage of adequately trained technical personnel, although technicians are skilled and can produce high quality specimens. Confusion of specimens sometimes occurred. Sets of histological slides were sometimes given to the pathologists incompletely, some blocks being left uncut. Histological specimens were not always clearly marked. The room for gross dissection had neither ventilation nor air conditioning. Biopsies were often left "until tomorrow", sometimes because of lacking clinical data. Telephonic contact with clinicians was relatively seldom. Pathologists obtain clinical information mainly from patients or their relatives, who bring specimens to the laboratory. This practice has advantages: pathologists can examine a patient or perform a fine-needle aspiration. If necessary, a patient can be asked to bring X-ray, CT, or other additional information; for example, a complicated diagnosis of a bone tumor (osteoblastoma in a child) was successfully made in this way and later confirmed by an external consultation. On the other hand, specimens are often put aside "until the patient comes", and can be left for many days. There were no special programs of quality control; although they would be useful for ensuring of more reliable work of the laboratory, preventing specimen confusion, guaranteeing cutting of all blocks, clear marking of specimens and so forth. No autopsies were performed in the Medical City of Baghdad. No special regulations existed with regard to the waste disposal, and the waste from the department of pathology was disposed together with other waste from the hospital. Used formalin and other solutions were purred out into the sewerage. Another drawback was an often inadequate formalin fixation of specimens in clinical departments, both of small biopsies and of large surgical specimens, which sometimes resulted in tissue autolysis (this problem was prominent also at the Basra Teaching Hospital). The problem was partly caused by lack of suitable containers for fixation, and the specimens were placed into plastic pockets. We discussed it with clinicians in the Medical City of Baghdad, and a tendency of improvement was noticed. 
To conclude optimistically, it must be said that health care in Iraq has essential prerequisites for successful development. Shortages and difficulties were partly caused by mismanagement at the time of the previous regime and are probably temporary in their nature. Unfortunately, health care authorities and hospital managers sometimes belittle and disregard some internally solvable problems, even if a solution can be found. Possible suggestions for those who will want to help out include different kinds of material aid (3), although supplies have been improving during last years (4). Considering shortage of modern professional literature, donations to Iraqi medical institutions of books, e.g. previous editions of handbooks and manuals becoming unnecessary after acquisition of newer editions, would help to improve diagnostics. Telepathology and online consultations, exemplified by the program International Consultants in Medicine (5), are also helpful for the same purpose. Volunteering and clinical attachments of foreign pathologists or other medical specialists are particularly useful because they enable to see internal problems from another viewpoint, which can be helpful in finding solutions. This approach would be useful also in the former Soviet Union (2).

\section{REFERENCES}

1. Jargin SV: Nursing and security in Iraqi hospitals: internally solvable problems. J Pak Med Assoc 2009, 59: 124

2. Jargin $S V$ : The practice of pathology in Russia: On the eve of modernization. Basic and Appl Pathol 2010, 3:70-73

3. Al Sheibani BI, Hadi NR, Hasoon T: Iraq lacks facilities and expertise in emergency medicine. BMJ 2006, 333: 847

4. Sansom C: The ghost of Saddam and UN sanctions. Lancet Oncol 2004, 5: 143-145

5. Voelker R: Iraq's prescription for violent barriers to health care: cell phones and e-mail. JAMA 2008, 300:637-638 